\title{
Morphometric and meristic variation in the Atlantic chub mackerel Scomber colias Gmelin, 1789 from the Moroccan coast
}

\author{
N. BOUZZAMMIT AND H. EL OUIZGANI \\ Laboratory of Oceanography and Fisheries, P. O. Box 8106, Faculty of Sciences, Ibn Zohr University \\ Dakhla Avenue Agadir, Morocco \\ e-mail: nadia.bouzzammit@edu.uiz.ac.ma
}

\section{ABSTRACT}

\begin{abstract}
Morphometric and meristic characters were used to study the variability between Scomber colias Gmelin, 1789 sampled from five locations in the Moroccan Atlantic coast. Eighteen morphometric measurements were taken using the image processing program, Image $J$ along with seven meristic characters. Univariate analysis of variance (ANOVA) performed by Tukey HSD post-hoc test showed significant differences for 14 standard morphometric measurements. In principal component analysis (PCA), PC1 was resolved as general size and PC2 was resolved as shape differences. Discriminant analysis indicated the existence of four morphometric groups of $S$. colias with minor overlapping, which suggested that there is a self-recruiting population. The proportion of correctly classified Sidi Ifni (SDF) sample to their original group was $96 \%$ and showed clear separation from other groups. We concluded that Sidi Ifni samples are morphologically distinct from S. colias of the other four localities which could be attributed to genetic bias or environmental factors.
\end{abstract}

Keywords: Agadir, Meristic, Morocco, Morphometric, Scomber colias

\section{Introduction}

The Atlantic chub mackerel Scomber colias Gmelin, 1789 (Family: Scombridae), is a fast growing, early maturing coastal pelagic species that may reach $50 \mathrm{~cm}$ in total length and 13 years of age (Castro et al., 2000). It has a cosmopolitan distribution in warm and temperate coastal waters of the Atlantic and the adjacent seas, such as the Mediterranean Sea, the Black Sea and the Adriatic Sea, on the continental shelf between 0 to $300 \mathrm{~m}$ (Collette et al., 1983; Castro et al., 2000; Infante et al., 2007), extending from the Bay of Biscay of the eastern Atlantic north to South Africa. Also, it is present along the coast of America, from Massachusetts to Florida, the Bahamas, Gulf of Mexico, southern Venezuela, Brazil, Uruguay and Argentina (Castro et al., 2000).

S. colias has earlier been described from the Atlantic coasts as a synonym of Scomber japonicus Houttuyn, 1782, but recent genetic studies confirmed that $S$. colias and $S$. japonicus are different species, one belonging to the Atlantic and the other to the Pacific (Infante et al., 2007; Catanese et al., 2010; Trucco and Buratti, 2017).

The chub mackerel $S$. colias has significant ecological and economic importance, globally and in Morocco as well, and therefore it is essential to develop knowledge base on their population and stock structure. The biometric field has been used by ichthyologists, to extract differences from the shape of specimens (Cadrin, 2000; Hermida et al., 2005; Infante, 2007). Morphometric measurements and meristic counts are widely applied in the biological field to study the intra or interspecific phenotypic variations among populations. Meristic characters are the number of discrete countable structures, independent of size and stable during growth and the morphometric characters are continuous characters describing aspects of body shape (Ihssen et al., 1981; Turan 2004; Erguden et al., 2009; Tarkeshwar et al., 2012) and are often been used to delineate stocks (Turan et al., 2006). So far, many studies have been carried out on chub mackerel, dealing with different aspects of biology such as diet, age, growth, reproduction and morphometry, along both Mediterranean and Atlantic coasts and most of them are related to S. japonicus (Baird, 1977; Carvalho et al., 2002; Perrotta et al., 2005; Bayhan, 2007; Cikes et al., 2011; Velasco et al., 2011; Wahbi et al., 2015; Ait Talborjt and El Ouizgani, 2016; Allaya et al., 2016). Such data available for $S$. colias from the Moroccan Atlantic Ocean are very scanty, even though the species form a commercial fishery in the region.

The present study investigated the variability in the morphometric and meristic characters among samples of $S$. colias collected from five distant localities situated along the Moroccan Atlantic coast. 


\section{Materials and methods}

\section{Sample collection}

Sampling was carried out from commercial landings of small fishing units and purse seiners. A total of 300 specimens of $S$. colias, were collected during winter in 2017, from five different fishing ports (Fig. 1), located along the Atlantic coast, namely El Jadida, Safi, Agadir, Sidi Ifni and Laayoune.

\section{Morphometric characters}

A total of 18 morphometric measurements (Erguden et al., 2009; Allaya et al., 2016; Gonzalez et al., 2016) to the nearest $1 \mathrm{~mm}$ were taken from 284 specimens (Table 1) using Image $J 1.50 \mathrm{~b}$, an image processing program developed for morphometric measurements using digital images (Abramoff et al., 2004; Schneider et al., 2012). The measurements comprised: total length (TL), fork length (FL), standard length (SL), pre-first dorsal fin length (PDL1), pre-second dorsal fin length (PDL2), pre-pectoral fin length (PPL), pre-ventral fin length (PVL), pre-anal length (PAL), head length (HL),

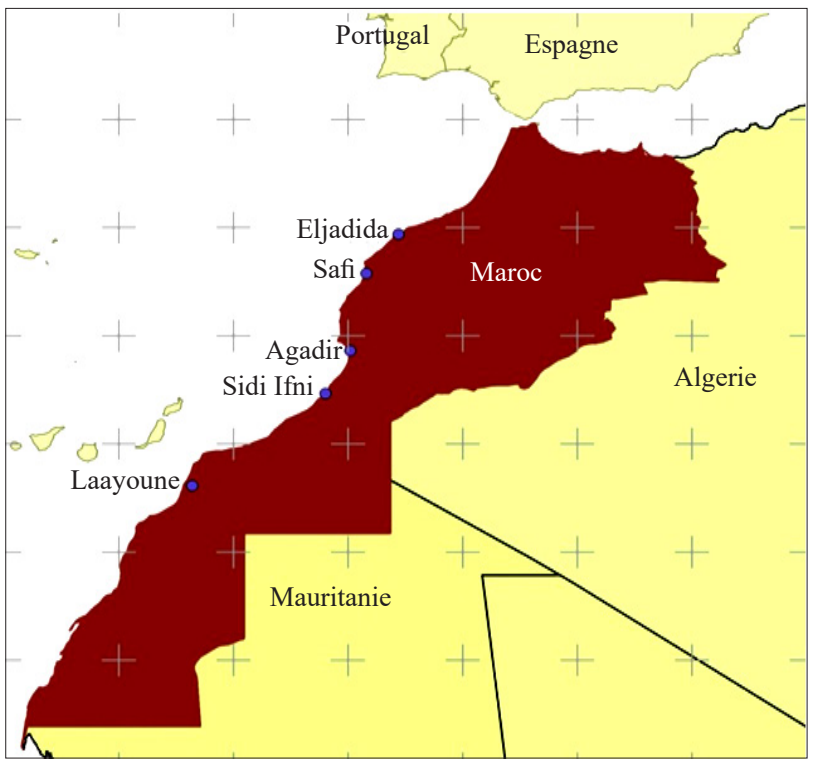

Fig. 1. Map of sampling locations for Scomber colias eye diameter (ED), pre-orbital length (POL), head depth (HD), snout length (SNL), body depth (BD), depth at first dorsal (DFD), depth at second dorsal (DSD), depth at anal (DA) and peduncle depth (PD) (Fig. 2).

\section{Meristic characters}

Seven meristic characters such as: number of first dorsal fin rays (DFR1), second dorsal fin rays (DFR2), anal fin rays (AFR), pectoral fin rays (PFR), ventral fin rays (VFR), dorsal finlets (DF) and ventral finlets (VF) were counted for each specimen by direct observation. After having completed all the measurements of the biological parameters, the samples were cooked in a steam apparatus, in order to count the vertebrae after removing the whole meat. All the samples were found to have 30 vertebrae.

\section{Statistical analysis}

As a first step, a simple analysis of variance was performed on the raw data (morphometric data) to test size heterogeneity among populations of different areas. The morphometric data were transformed to $\log _{10}$ before analysis to reach better approximation to multivariate normality and to eliminate size effect from the raw data (Elliot et al., 1995). All morphometric measurements were standardised according to the following formula (Elliott et al., 1995):

$$
\mathrm{M}_{\text {adj }}=\mathrm{M}\left(\mathrm{L}_{\mathrm{s}} / \mathrm{L}_{0}\right)^{\mathrm{b}}
$$

where $\mathrm{M}=$ Original morphometric measurement, $\mathrm{M}_{\text {adj }}=$ Size adjusted measurement, $\mathrm{L}_{\mathbf{0}}=$ Standard length of the specimen and $\mathrm{L}_{\mathrm{s}}=$ Overall mean of standard length of all fish from all samples for each variable. The parameter b was estimated for each character from the observed data as the slope of the regression of $\log \mathrm{M}$ on $\log \mathrm{L}_{0}$ (Elliott et al., 1995; Elliott et al., 1995; Tudela,1999; Turan, 2004; Allaya et al., 2016).

To ensure that data transformation was effective in removing the effect of size from the whole morphometric data, the correlation coefficient between transformed variables and standard length were calculated (Turanet et al., 2006; Erguden et al., 2009; Gonzalez, 2016). When

Table 1. Sampling details of $S$. colias used in the study

\begin{tabular}{|c|c|c|c|c|c|}
\hline \multirow{2}{*}{ Sampling location } & \multirow{2}{*}{ Sample size $(\mathrm{N})$} & \multicolumn{3}{|c|}{ Standard length range (mm) } & \multirow{2}{*}{$\begin{array}{l}\text { Sex } \\
(M / F)\end{array}$} \\
\hline & & Min. & Max. & Mean $(X)$ & \\
\hline SAF (SAFI) & 56 & 161.7 & 213.9 & 181.2 & $30 \AA / 26$ 車 \\
\hline JD (EL JADIDA) & 61 & 172.0 & 255.6 & 197.6 & $26 \overbrace{}^{\lambda} / 35 q$ \\
\hline AG (AGADIR) & 64 & 168.5 & 287.3 & 206.6 & $19 \hat{\delta} / 45+$ \\
\hline SDF (SIDI IFNI) & 52 & 237.7 & 410.6 & 303.8 & $20{ }^{\lambda} / 32$ + \\
\hline LA (LAAYOUNE) & 51 & 192.8 & 270.0 & 238.7 & $21 \delta / 30+$ \\
\hline
\end{tabular}




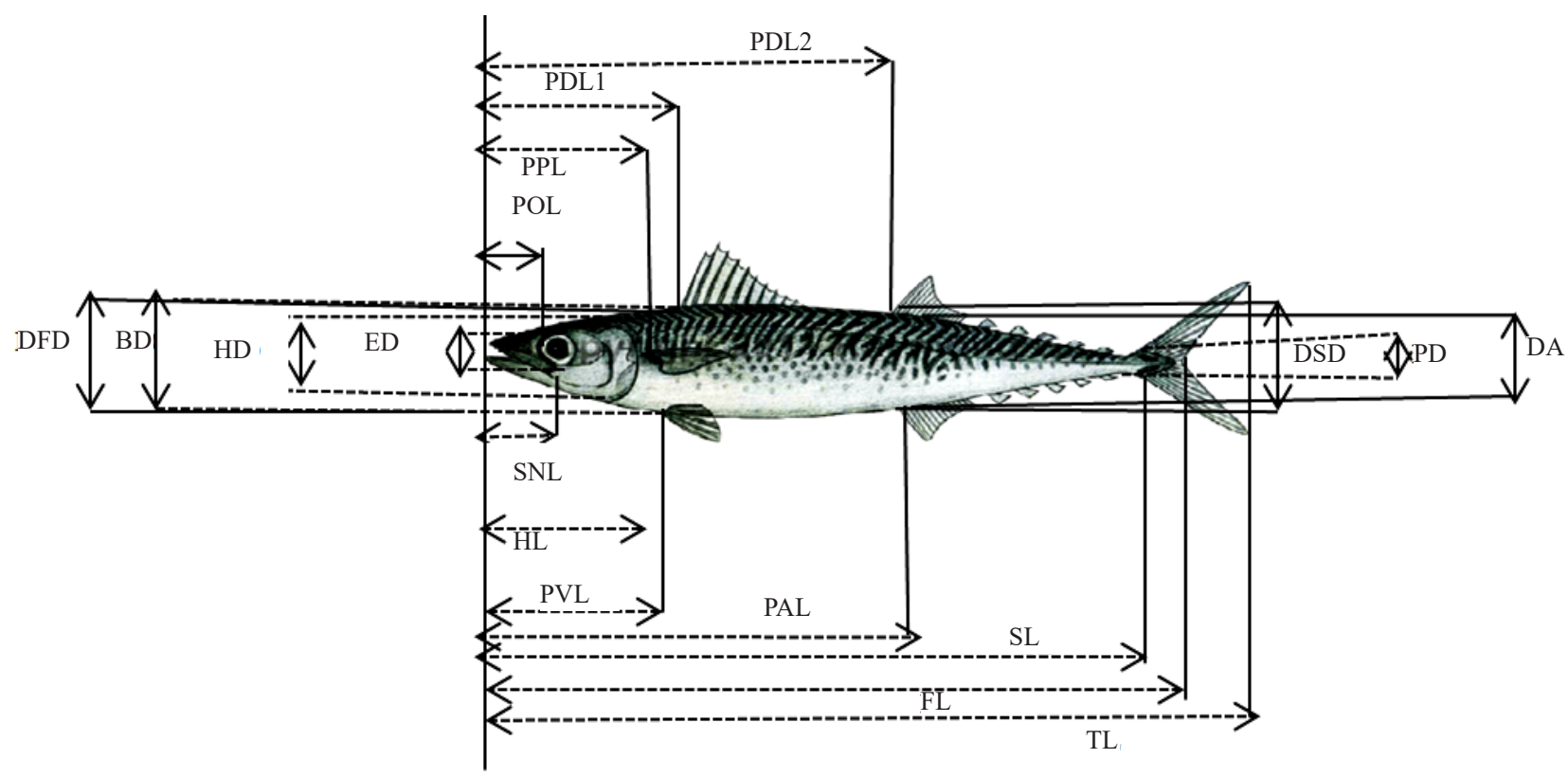

Fig. 2. Schematic drawing of S. colias showing details of various measurements: BD-Body depth, HD-Head depth, ED-Eye diameter, POL-Pre-orbital length, PPL-Pre-pectoral fin length, PDL1-Pre-first dorsal fin length, PDL2-Pre-second dorsal fin length, SNL-Snout length, HL-Head length, PVL-Pre-ventral fin length, PAL-Pre-anal fin length, FL-Fork length, SL-Standard length, TL-Total length, DFD-Depth at first dorsal, DSD-Depth at second dorsal, DA-Depth at anal and PD-Peduncle depth. (Drawing by Ray Simpson - modified)

the standardised measurements showed no significant correlation with standard length (SL), it was deemed that size effect had been removed successfully.

Univariate analysis ANOVA was used to evaluate differences for each morphometric character among the five populations (Turanet et al., 2006) and Tukey post-hoc test was used for pair-wise comparison. The size compensated data were subjected to principal component analysis (PCA), a multivariate statistical method that reduces a group of variables into smaller numbers and visualises the variation in lower dimensions. Linear discriminant analysis was used to reclassify samples and to show the best separation between groups. Kruskal-Wallis test was used to examine variation in meristic characters among different samples. All statistical analyses were carried out using $\mathrm{R}$ ver 3.3.3. The packages used in this current study were: ade4, FactoMineR and MASS (Chessel et al., 2004; Dray and Dofour 2007; Dray et al., 2007; Le et al., 2008).

\section{Results}

\section{Morphometric analysis}

Tukey post-hoc test demonstrated that Sidi Ifni (SDF) samples differed significantly from Agadir (AG) and Safi (SAF) samples by 16 morphometric measurements; from El Jadida (JD) samples by 15 measurements and Laayoune samples by 13 measurements. El Jadida (JD) samples differed significantly from Agadir samples by 12 measurements, from Laayoune samples by 9 and Safi samples by 8 measurements. S. colias samples from Laayoune (LA) differed significantly from Agadir samples by 15 measurements and Safi samples by 12 measurements. Safi samples differed significantly from Agadir samples by 11 measurements (Table 2).

In PCA, the first component factor (PC1) accounted for $56.82 \%$ of the overall variance, while the second component factor (PC2) explained $23.85 \%$. All variables were positively correlated with the first component PC1 (Fig. 3). The first two components in the PCA, covered majority of the total variability; which accounted for $80.67 \%$.

Discriminant analysis showed four natural groups. The overall assignment of individuals into their original population by linear discriminant analysis was low $(80 \%)$ (Table 3). The proportion of correctly classified Sidi Ifni (SDF) sample to their original group was highest (96\%) followed by Agadir (87\%), El Jadida (80\%), Laayoune $(90 \%)$ and Safi (83\%) samples (Fig. 4).

\section{Meristic analysis}

All meristic counts of samples from the five locations were analysed using the Kruskal-Wallis test, which showed significant difference $(\mathrm{p}<0.05)$ in the first dorsal 
Table 2. ANOVA results of morphometric measurements performed with the Tukey HSD post-hoc test (a, b, c and d = means of characters)

\begin{tabular}{llllllll}
\hline Characters & F value $(4,279)$ & p-value & Sample 1 (JD) & Sample 2 (SAF) & Sample 3 (AG) & Sample 4 (SDF) & Sample 5 (LA) \\
\hline SL & 263.2 & $<0.001$ & $2,294 \mathrm{c}$ & $2,257 \mathrm{~d}$ & $2,312 \mathrm{c}$ & $2,480 \mathrm{a}$ & $2,377 \mathrm{~b}$ \\
PDL1 & 45.22 & $<0.001$ & $1,919 \mathrm{~b}$ & $1,908 \mathrm{c}$ & $1,904 \mathrm{c}$ & $1,940 \mathrm{a}$ & $1,921 \mathrm{~b}$ \\
PDL2 & 42.05 & $<0.001$ & $2,177 \mathrm{bc}$ & $2,172 \mathrm{~d}$ & $2,174 \mathrm{~cd}$ & $2,187 \mathrm{a}$ & $2,179 \mathrm{~b}$ \\
PAL & 25.01 & $<0.001$ & $2,197 \mathrm{c}$ & $2,194 \mathrm{c}$ & $2,194 \mathrm{c}$ & $2,205 \mathrm{a}$ & $2,201 \mathrm{~b}$ \\
PPL & 37.38 & $<0.001$ & $1,799 \mathrm{~b}$ & $1,790 \mathrm{bc}$ & $1,771 \mathrm{~d}$ & $1,821 \mathrm{a}$ & $1,786 \mathrm{c}$ \\
PVL & 55.97 & $<0.001$ & $1,878 \mathrm{bc}$ & $1,870 \mathrm{c}$ & $1,859 \mathrm{~d}$ & $1,906 \mathrm{a}$ & $1,886 \mathrm{~b}$ \\
HL & 37.18 & $<0.001$ & $1,787 \mathrm{~b}$ & $1,777 \mathrm{~b}$ & $1,757 \mathrm{c}$ & $1,808 \mathrm{a}$ & $1,785 \mathrm{~b}$ \\
BD & 23.48 & $<0.001$ & $1,561 \mathrm{c}$ & $1,554 \mathrm{c}$ & $1,621 \mathrm{~b}$ & $1,650 \mathrm{a}$ & $1,639 \mathrm{a}$ \\
ED & 26.76 & $<0.001$ & $1,157 \mathrm{bc}$ & $1,160 \mathrm{bc}$ & $1,142 \mathrm{c}$ & $1,211 \mathrm{a}$ & $1,168 \mathrm{~b}$ \\
POL & 181.9 & $<0.001$ & $1,226 \mathrm{ab}$ & $1,176 \mathrm{c}$ & $1,170 \mathrm{c}$ & $1,246 \mathrm{a}$ & $1,206 \mathrm{~b}$ \\
HD & 11.8 & $<0.001$ & $1,538 \mathrm{~d}$ & $1,521 \mathrm{e}$ & $1,562 \mathrm{c}$ & $1,597 \mathrm{a}$ & $1,575 \mathrm{~b}$ \\
SNL & 34.21 & $<0.001$ & $1,393 \mathrm{~b}$ & $1,382 \mathrm{~b}$ & $1,363 \mathrm{c}$ & $1,441 \mathrm{a}$ & $1,397 \mathrm{~b}$ \\
DFD & 187.4 & $<0.001$ & $1,565 \mathrm{c}$ & $1,557 \mathrm{c}$ & $1,630 \mathrm{~b}$ & $1,653 \mathrm{a}$ & $1,643 \mathrm{~b}$ \\
DSD & 197 & $<0.001$ & $1,498 \mathrm{c}$ & $1,483 \mathrm{~d}$ & $1,548 \mathrm{~b}$ & $1,592 \mathrm{a}$ & $1,588 \mathrm{a}$ \\
DA & 213.5 & $<0.001$ & $1,466 \mathrm{c}$ & $1,446 \mathrm{~d}$ & $1,520 \mathrm{~b}$ & $1,564 \mathrm{a}$ & $1,553 \mathrm{a}$ \\
PD & 145 & $<0.001$ & $0,747 \mathrm{~d}$ & $0,718 \mathrm{e}$ & $0,788 \mathrm{c}$ & $0,886 \mathrm{a}$ & $0,820 \mathrm{~b}$
\end{tabular}

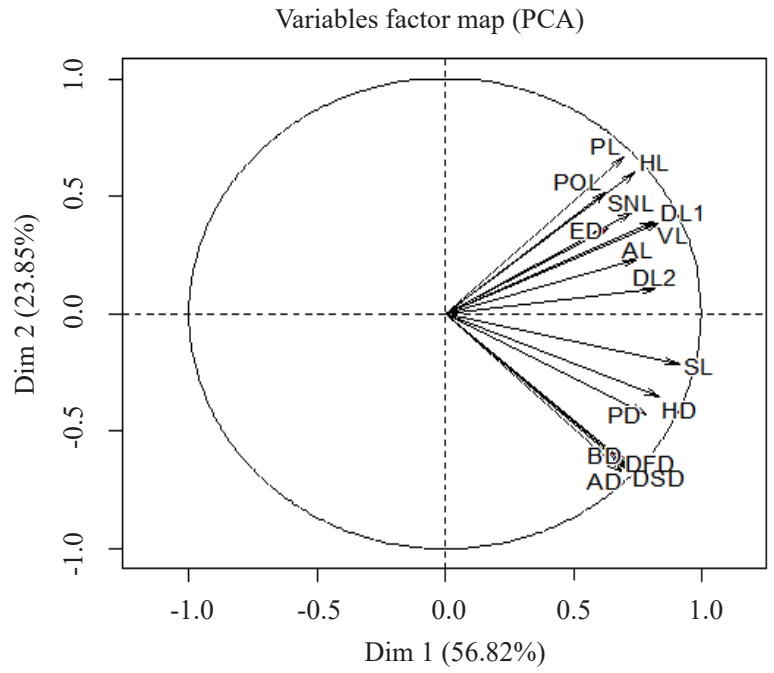

Fig. 3. Results of principal component analysis correlation circle (PCA)

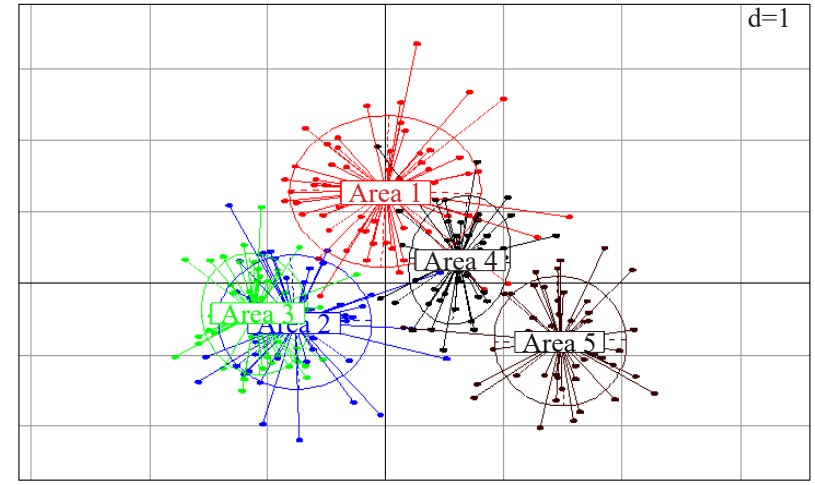

Fig. 4. Results from discriminant analysis (AREA1=Agadir, AREA2 $=$ EL Jadida, AREA3=Safi, AREA4=Laayoune, AREA5=Sidi Ifni)

Table 3. Classification matrix of individuals reallocated in each group, in the validation of discriminant analysis for morphometric data. Rows are the original sample group and columns are the reallocated group

\begin{tabular}{llllllll}
\hline Sample groups & Correction & AGADIR & ELJADIDA & LAAYOUNE & SAFI & SIDI IFNI & Total \\
\hline AGADIR & $87 \%$ & 56 & 0 & 4 & 1 & 3 & 64 \\
ELJADIDA & $80 \%$ & 1 & 49 & 2 & 9 & 0 & 61 \\
LAAYOUNE & $90 \%$ & 4 & 1 & 46 & 0 & 0 & 51 \\
SAFI & $83 \%$ & 0 & 9 & 0 & 47 & 0 & 56 \\
SIDI IFNI & $96 \%$ & 0 & 0 & 2 & 0 & 50 & 52 \\
\hline Total & & 61 & 59 & 54 & 57 & 53 & 284 \\
\hline
\end{tabular}

fin rays (DFR1), anal fin rays (AFR) and pectoral fin rays (PFR), whereas no significant differences were seen in VEF and DF2 when compared for the five areas (Table 4).
The meristic characters of $S$. colias showed minor differences, for the number of first dorsal fin rays. El Jadida and Safi samples presented the same range 
Table 4. Kruskal-Wallis test of meristic characters for five locations, $\mathrm{p}=0.05, \mathrm{df}=4 \mathrm{H} 0$ : Null hypothesis, $\mathrm{H} 1$ : Alternative hypothesis

\begin{tabular}{llll}
\hline $\begin{array}{l}\text { Meristic } \\
\text { characters }\end{array}$ & $\chi^{2}$ value & $\mathrm{p}$-value & Hypotheses \\
\hline DFR1 & 33.144 & $1.116 \mathrm{e}^{-06}$ & $\mathrm{H} 1$ \\
DFR2 & 5.0825 & 0.2789 & $\mathrm{H} 0$ \\
AFR & 9.6719 & 0.04633 & $\mathrm{H} 1$ \\
VFR & 2.69 & 0.611 & $\mathrm{H} 0$ \\
PFR & 111.95 & $<2.2 \mathrm{e}^{-16}$ & $\mathrm{H} 1$ \\
\hline
\end{tabular}

(8-10), while Agadir, Sidi Ifni and Laayoune showed different ranges of 7-11; 7-9 and 7-10 respectively. For the number of second dorsal fin rays, the same range (11-12) was observed for all five populations. With respect to anal fin rays and ventral fin rays, El Jadida, Safi, Sidi Ifni and Laayoune populations presented similar ranges of 11-12 and 6-6 respectively, while it was different for Agadir population (10-12) and (5-6) respectively. The number of pectoral fin rays was found to be similar for three populations (18-19), except for Agadir (16-20) and Safi (17-19) samples (Table 5).

\section{Discussion}

The results obtained by ANOVA and Tukey post-hoc test demonstrated significant variation in the morphometric characters across the five sampling locations. The samples of Sidi Ifni differed from that of the other four locations (Agadir, El Jadida, Laayoune and Safi) in almost all morphometric measurements, except for selected measurements like pre-orbital length (POL), which was found to be the same as El Jadida and Laayoune samples. Body depth (BD), depth at second dorsal (DSD) and depth at anal (DA) of Sidi Ifini samples were the same as that of Laayoune. Head depth (HD) and peduncle depth (PD) were the morphometric measurements that differed among all samples.

Results of PCA demonstrated that all linear measurements had a positive linear correlation with the first principal components $\mathrm{PC} 1$. The second principal components (PC2) showed a negative linear correlation with body depth (BD), head depth (HD), standard length (SL), depth at anal (DA), depth at first dorsal (DFD), depth at second dorsal (DSD) and peduncle depth (PD). According to Teissier (1960), the effect of size accounted for the first principal component PC1. The second component PC2 is used to visualise variations in shape. The morphometric results obtained by linear discriminant analysis revealed the existence of four clear groups which confirmed the results obtained by PCA. The first group included AREA1 (Agadir); second group AREA2 (El Jadida) and AREA3

Table 5. Variations in meristic characters from five different landing sites

\begin{tabular}{lllll}
\hline Meristic character & Locality & Sample size (N) & Range (Min-Max) & Median \\
\hline DFR1 & El Jadida & 61 & $8-10$ & 9 \\
& Safi & 56 & $8-10$ & 9 \\
& Agadir & 64 & $7-11$ & 9 \\
& Sidi ifni & 52 & $7-9$ & 9 \\
\hline Laayoune & 51 & $7-10$ & 12 \\
& El Jadida & 61 & $11-12$ & 12 \\
& Safi & 56 & $11-12$ & 12 \\
& Agadir & 64 & $11-12$ & 12 \\
& Sidi ifni & 52 & $11-12$ & 12 \\
\hline AFR & Laayoune & 51 & $11-12$ & 12 \\
& El Jadida & 61 & $11-12$ & 12 \\
& Safi & 56 & $11-12$ & 12 \\
& Agadir & 64 & $10-12$ & 12 \\
\hline VFR & Sidi ifni & 52 & $11-12$ & 12 \\
& Laayoune & 51 & $11-12$ & 6 \\
& El Jadida & 61 & $6-6$ & 6 \\
& Safi & 56 & $6-6$ & 6 \\
& Agadir & 64 & $5-6$ & 6 \\
& Sidi ifni & 52 & $6-6$ & 6 \\
\hline & Laayoune & 51 & $6-6$ & 18 \\
& El Jadida & 61 & $18-19$ & 18 \\
& Safi & 56 & $17-19$ & 18 \\
& Agadir & 64 & $18-19$ & 18 \\
\hline
\end{tabular}


(Safi); the third group AREA3 (Laayoune) and the fourth group AREA4 (Sidi Ifni). The second group comprising AREA2 (El Jadida) and AREA 3 (Safi) showed a major overlap, indicative of homogeneity. This may be explained by the geographic proximity of El Jadida and Safi sharing same environmental conditions. The first group AREA1 (Agadir) and the third group AREA4 (Laayoune) are close to each other, but still showed a significant difference in all morphometric characters, which may be due to variation in environmental conditions as these areas experience variability in upwelling intensity (Berrada et al., 2017). The fourth group AREA4 (Sidi Ifni), which is isolated from the other groups showed huge difference from the other four populations in morphometric characters. The differences observed among four groups may suggest the relationship between phenotypic divergence and geographic distance, explaining the limited migration between the five distant areas, viz., El Jadida, Safi, Agadir, Laayoune and Sidi Ifni. The vast variability of size observed between samples from Sidi Ifni and other areas, could also be attributed to the way of fishing, since the fishermen use pelagic longlines instead of purse-seine to catch chub mackerel in Sidi Ifni. On the other hand, different environmental factors such as temperature and salinity as well as fishing intensity and availability of food may also contribute towards size variability (Tudela, 1999; Tzeng, 2004; Turan et al., 2006; Balayet et al., 2015; Allaya et al., 2016). High morphometric differentiation of Sidi Ifni samples suggests that either there may be sub-species of $S$. colias or this perhaps indicates growth responses to different habitats arising from ecological and oceanographical conditions (Erguden et al., 2009).

Studies on the spatio-temporal dynamism of temperature and surface salinity of the coastal zone of Morocco between Spartel Cap and Juby Cap suggest seasonal fluctuations between coastal and offshore water because of upwelling activity (Furnestin, 1959; Makaoui et al., 2005). During winter season, the coastal waters of upwelling area (Safi-Essaouira and Sidi Ifni-Draa) are distinguished by a decrease in temperature and salinity (Furnestin, 1959; Makaoui et al., 2005). The pelagic ecosystem of the Moroccan Atlantic coast has been reported to be influenced by the spatio-temporal variability of upwelling (Bessa et al., 2018).

Roldan et al. (2000) reported that, head size is a critical as well as a principal factor influencing variations between populations in South-West Atlantic Ocean. The variations may be attributable to growth responses to different oceanographic and ecological conditions (Roldan et al., 2000). Erguden et al. (2009) and Allaya (2016) reported that these morphometric characters also show variations in the Mediterranean, Tunisian Sea, the
North-Eastern Mediterranean, Aegan, Marmara and the Black Sea.

Results obtained from Kruskal-Wallis, revealed a significant difference in some meristic characters among samples; such as dorsal fin rays 1, anal fin rays and pectoral fin rays. Perhaps, this variation in meristic characters could be attributed to genetic structure or environmental factors. Major variability was observed in two meristic characters viz., the first dorsal fin rays (DFR1) and the pectoral fin rays (PFR). El Jadida and Safi populations had the same number of first dorsal fin rays (8-10) which were supposed to be from the same population because of similar environmental conditions and geographical proximity, while Agadir, Sidi Ifni, Laayoune samples had different range of 7-11; 7-9; and 7-10 respectively. The number of pectoral fin rays were found similar for El Jadida, Laayoune and Sidi Ifni (18-19), which were found different for Agadir (16-20) and Safi (17-19) samples. Chase (2014) reported that the meristic characters are partially affected by environmental conditions during embryonic stages and therefore, the variations in meristic counts can indicate some degree of geographic separation between populations during early life stages. In general, fishes are sensitive to environmental changes, which make them adapt quickly by changing necessary morphometric characters (Hossain et al., 2010; Mollah et al., 2012).

In the present study, considerable morphological variability was found between samples of $S$. colias from Sidi Ifni and from the four other localities in the Moroccan coast. Morphological studies on $S$. colias are scarce in the Moroccan Atlantic coast and therefore, further studies need to be carried out on the morphological characters of the chub mackerel populations from north and south Morocco coasts for deriving more conclusive inferences. Also, it would be better to use molecular genetic markers such as microsatellites (Shaw et al., 1999; Turan, 2015) to examine genetic component of phenotypic differentiation between different locations.

\section{References}

Abramoff, M. D., Magalhaes, P. J. and Ram, S. J. 2004. Image processing with Image. J. Biophotonics Int., 11(7): $36-42$.

Ait Talborjt, E. and EL Ouizgani, H. 2016. Analysis of the mackerel diet (Scomber japonicus Houttuyn, 1782) in the Moroccan Atlantic cohort (Safi, Essaouira, Agadir, Tarfaya). J. Mater. Environ. Sci., 7(12): 4722-4729 (In French).

Allaya, H., Ben Faleh, A., Rebaya, M., Zrelli, S., Hajjej, G., Hattour, A., Quignard, J. P. and Trabelsi, M. 2016. Biologic characteristics of Scomber japonicus (Houttuyn, 1782) in 
Tunisian waters (Central Mediterranean Sea). Cah. Biol. Mar., 57: 195-207.

Baird, D. 1977. Age, growth and aspects of reproduction of the mackerel Scomber japonicus in South African waters (Pisces: Scombridae). J. Zoologica Africana, 12(2): 347-362. DOI: 10.1080/00445096.1977.11447580.

Balayet, Md. H., Bhowmik, S., Majumdar, P. R., Saha, P. and Ul-Islam, Md. R. 2015. Landmark-based morphometric and meristic variations in populations of mullet, Rhinomugil corsula (Hamilton, 1822) in Bangladesh. World J. Fish Mar. Sci., 7(1): 12-20. DOI: 10.5829/idosi. wjfms.2015.7.1.91163.

Berrada, A., Benazzouz, A., Demarcq H., Lamrini A., Berrahou, A. and Hilmi K. 2017. Spatio-temporal characterisation of primary production in north-west Africa using MODISA satellite imagery. Rev. Mar. Sci. Agron. Vet., 5(3): 269-286.

Bessa, I., Makaoui, A., Hilmi, K., Idrissi, M., Agouzouk, A. and Afifi, M. 2018. Analysis of coastal upwelling index along the Moroccan Atlantic coast using wavelets from 1967 to 2016. Int. J. Sci. Eng. Res., 9(3): 552-559.

Bayhan, B. 2007. Growth characteristics of the chub mackerel (Scomber japonicus Houttuyn, 1782) in Izmir Bay (Aegean Sea, Turkiye). J. Anim. Vet. Advances, 6(5): 627-634.

Cadrin, S. X. 2000. Advanced in morphometric analysis of fish stock structure. Rev. Fish Biol. Fish., 10: 91-112. DOI: 10.1023/A:1008939104413.

Carvalho, N., Perrotta, R. G. and Isidro, E. J. 2002. Age, growth and maturity in the chub mackerel (Scomber japonicus Houttuyn, 1782) from the Azores. Life Mar. Sci., 19A: 93-99.

Castro, H. J. J. and Ortega, S. A. T. 2000. Synopsis of biological data on the chub mackerel (Scomber japonicus Houttuyn, 1782). FAO. Fisheries Synopsis, No. 157.

Catanese, G., Manchado, M. and Infante, C. 2010. Evolutionary relatedness of mackerels of the genus Scomber based on complete mitochondrial genomes: strong support to the recognition of Atlantic Scomber colias and Pacific Scomber japonicus as distinct species. Gene, 452: 35-43. doi: 10.1016/j.gene.2009.12.004.

Chase, P. D. 2014. Meristics. In: Steven Cadrin, Lisa A. Kerr and Stefano Mariani (Eds.), Stock identification methods: Application in fishery science, $2^{\text {nd }}$ edn. Academic Press, New York, USA, p. 171-184.

Chessel, D., Dufour, A. B. and Thioulouse 2004. The ade4 package-I- One-table methods. R News, 4: 5-10.

Cikes Kec V. and Zorica, B. 2011. Biometry markers of chub mackerel, Scomber japonicus Houttuyn, 1782, in the Adriatic Sea. Acta Adriat., 52(2) : 215-222.

Collette, B. B. and Nauen, C. E. 1983. FAO species catalogue. Scombrids of the world. An annotated and illustrated catalogue of tunas, mackerels, bonitos and related species known to date. FAO Fisheries Synopsis, 125, vol. 2.
Dray, S. and Dufour, A. B. 2007. The ade4 package: implementing the duality diagram for ecologists. J. Statistical Software, 22(4): 1-20. DOI: 10.18637/jss.v022.i04.

Dray, S., Dufour, A. B. and Chessel, D. 2007. The ade4 packageII: Two-table and K-table methods. $R$ News, 7(2): 47-52. doi.org/10.1111/j.1095-8649.1995.tb05962.x.

Elliott, N. G., Haskard, K. and Koslow, J. A. 1995. Morphometric analysis of orange roughy (Hoplostethus atlanticus) off the continental slope of southern Australia. J. Fish. Biol., 46: 202-220.

Erguden, D., Ozturk, B., Erdogan, Z. A. and Turan, C. 2009. Morphologic structuring between populations of chub mackerel Scomber japonicus in the Black, Marmara, Aegean and north-eastern Mediterranean seas. Fish. Sci., 751: $29-135$

Furnestin, J. 1959. The hydrology of Atlantic Morocco from 1949 to 1953. Rev. Trav. Inst. Scient. Techn. Peche. Mar., 23(1): 5-77 (In French).

Gonzalez, M., Rodriguez, A., Angon, J. M. E., Martinez, A., Garcia, A. and Pena, F. 2016. Characterisation of morphological and meristic traits and their variations between two different populations (wild and cultured) of Cichlasoma festae, a species native to tropical Ecuadorian rivers. Arch. Anim. Breed., 59: 435-444. DOI: 10.5194/aab59-435-2016.

Hermida, M., Fernandez, J. C., Amaro, R. and Miguel, E. S. 2005. Morphometric and meristic variation in Galician threespine stickleback populations, north-west Spain Environ. Biol. Fishes, 73: 189-200. DOI: 10.1007/s10641005-2262-0.

Hossain, M. A. R., Nahiduzzaman, Md., Saha, D., HabibaKhanam, Mst. U. and Alam, Md. S. 2010. Landmark-based morphometric and meristic variations of the endangered carp, kalibaus Labeo calbasu from stocks of two isolated rivers, the Jamuna and Halda and a hatchery. Zool. Stud., 49(4): 556-563.

Ihssen, P. E., Booke, H. E., Casselman, J. M., Mc Glade, J., Payne, N. R. and Utter, F. M. 1981. Stock identification: materials and methods. J. Can. Fish. Aquat. Sci., 38 1838-1855.

Infante, C., Blanco, E., Zuasti, E., Crespo, A. and Manchado, M 2007. Phylogenetic differentiation between Atlantic Scomber colias and Pacific Scomber japonicus based on nuclear DNA sequences. Genetica, 130: 1-8. DOI: 10.10 07/s10709-006-0014-5.

Le, S., Josse, J. and Husson, F. 2008. Facto Mine R: An R package for multivariate analysis. J. Statistical Software, 25(1): 1-18. DOI: 10.18637 /jss.v025.i01.

Makaoui, A., Orbi, A., Hilmi, K., Zizah, S., Larissi, J. and Talbi, M. 2005. The upwelling of the Atlantic coasts of Morocco between 1994 and 1998. C. R. Geosci., 337: 1518-1524 (In French) 
Mollah, M. F. A., Yeasmine, S., Hossen, M. B. and Ahammad, A. K. S. 2012. Landmark-based morphometric and meristic variations of Glossogobius giuris in three stocks. J. Bangladesh Agric. Univ., 10(2): 375-384. DOI: 10.3329/ jbau.v10i2.14931.

Roldan, M. I., Perrotta, R. G., Cortey, M. and Pla, C. 2000. Molecular and morphologic approaches to discrimination of variability patterns in chub mackerel, Scomber japonicus. J. Exp. Mar. Biol. Ecol., 253: 63-74.

Perrotta, R. G., Carvalho, N. and Isidro, E. 2005. Comparative study on growth of chub mackerel (Scomber japonicus Houttuyn, 1782) from three different regions: NW Mediterranean, NE and SW Atlantic. Rev. Invest. Desarr. Pesq., 1767-79.

Schneider, C. A., Rasband, W. S. and Eliceiri, K. W. 2012. NIH Image to Image J: 25 years of image analysis. Nat. methods, 9(7): 671-675. DOI: 10.1038/nmeth.2089.

Shaw, P. W., Turan, C., Wright, J. M., O'connell, M. and Carvalho, G. R. 1999. Microsatellite DNA analysis of population structure in Atlantic herring (Clupea harengus), with direct comparison to allozyme and mtDNA RFLP analyses Heredity, 83: 490-499. DOI: 10.1038/sj.hdy.6885860.

Tarkeshwar, K., Chakraborty, S. K., Jaiswar, A. K., Sandhya, K. M. and Debabrata, P. 2012. Biometric studies on Johnieops sina (Cuvier, 1830) along Ratnagiri coast of Maharashtra. Indian J. Fish., 59(1): 7-13.

Teissier, G. 1960. Relative growth in the physiology of crustacea. Academic Press, New York, USA, p. 537-560.

Trucco, M. I. and Buratti, C. C. 2017. Taxonomic review of Argentine mackerel Scomber japonicus (Houttuyn, 1782) by phylogenetic analysis. Mol. Biol. Res. Commun., 6(3), 141-152.

Tudela, S. 1999. Morphological variability in a Mediterranean, genetically homogeneous population of the European anchovy, Engraulis encrasicolus. Fish. Res., 42: 229-243. DOI: 10.1016/S0165-7836(99)00052-1.

Turan, C. 2015. Microsatellite DNA reveals genetically different populations of Atlantic bonito Sarda sarda in the Mediterranean Basin. Biochem. Syst. Ecol., 63, 174-182.

Turan, C. 2004. Stock identification of Mediterranean horse mackerel (Trachurus mediterraneus) using morphometric and meristic characters. ICES J. Mar. Sci., 61: 774-781. doi.org/10.1016/j.icesjms.2004.05.001.

Turan, C., Oral, M., Ozturk, B. and Duzgunes, E. 2006. Morphometric and meristic variation between stocks of bluefish (Pomatomus saltatrix) in the Black, Marmara, Aegean and north-eastern Mediterranean seas. Fish. Res., 79: 139-147. DOI: 10.1016/j.fishres.2006.01.015.

Tzeng, T. D. 2004. Morphological variation between populations of spotted mackerel Scomber australasicus of Taiwan. Fish. Res., 68: 45-55. DOI: 10.1016/j.fishres.2004.02.011.

Velasco, E. M., Arbol, J. Del, Baro, J. and Sobrino, I. 2011. Age and growth of the Spanish chub mackerel Scomber colias off southern Spain: a comparison between samples from the NE Atlantic and the SW Mediterranean. Revista de Biologia Marina y Oceanografia, 46: 27-34.

Wahbi, F., Tojo, N., Ramzi, A., Somoue, L., Manchih, K. and Errhif, A. 2015. Seasonal and size dependent variability in diet of Scomber colias (Gmelin, 1789) of the Atlantic Coast of the North-west Africa. Int. J. Adv. Res., 3(12): 485- 497. 